Conservancy by the executors of the late Lord Egerton of Tatton, in accordance with his wishes. The area is to be declared a National Nature Roservo. Thousands of ducks which have learned to rely on the Mere as a sanctuary will thus continue to have the strict protection given during Lord Egerton's lifetime. The neighbouring Tatton Park, with its meres, having already been handed over to the National Trust and the Cheshire County Council, will provide for the recreational needs of the public. The area given to the Conservancy consists of 195 acres, and a nature reserve agreement with the new owner and the farmers of land immediately overlooking the Mere will cover an additional 183 acres. The hydro-biology of the area is of great interest and its supreme value as a winter resort for wildfowl, as well as a breeding-place for certain aquatic birds, is partly due to the strict control over access and disturbance maintained by the late Lord Egerton. In spring and autumn many migrant birds may be seen there resting on passage, and some rare species have been recorded. The late $\mathrm{A}$. W. Boyd carried out numerous and detailed observations there for at least forty years and his work has made a great contribution to our knowledge of its bird fauna, which his friends hope to commemorete by building an observation post overlooking the Mere.

\section{Peak District National Park}

The third of the official guide books to Britain's National Parks has been prepared by the Peak Park Planning Board in association with the National Parks Commission, under the editorship of Patrick Monkhouse (National Park Guides, No. 3: Peak District. Pp. viii $+90+26$ plates. London: H.M. Stationery Office, 1960. 5s. net). Among the authoritative contributors is Lt.-Col. Gerald Haythornthwaite, who deals with the building traditions to be found in the Peak. Other contributions describe the geological structure and scenery of this National Park, its animal and plant life, and the marks made by man's occupation of the land since early times. There are also chapters on farming and industry in the Park to-day, as well as an account of the work done by the Peak Park Planning Board in preserving the beauty of the varied landscape and promoting its enjoyment. That the facilities of the Park are appreciated is shown by the way natives of grim industrial areas like South Lancashire, North Staffordshire and Sheffield seek solace in its open spaces. The guide book contrins a gazetteer of places of interest which would be especially appreciated by visitors.

\section{Changes in Sea-Level recorded in New Zealand}

HuTton's doctrine that the present is the key to the past has been taken increasingly to heart by geologists in recent years. The sedimentary processes operating on the continental shelves and in various intertidal environments have received widespread attention since the War. Before older sedimentary rocks can be interpreted in terms of the Holocene, however, it is necessary to allow for any deviations from the norm which may have resulted from the Pleistocene glaciation. In particular, small changes in sea-level can influence sedimentation profoundly, and it is essential to determine any changes that have occurred as accurately as possible. Further evidence concerning world-wide fluctuations has recently been brought to light. In northern North Island, New Zealand, J. C. Schofield (N.Z. J. Geol. and Geophys., 3, 467 ; 1960) has been able to trace a number of elevated chenier ridges and to date the origin of several by radiocarbon determinations on shells. The area is believed to have been tectonically stable since the end of the Miocene period, so that the levels of the ridges may be interpreted in terms of changes in sealevel. Neglecting minor changes, the sea-level appears to have fallen $7 \mathrm{ft}$. from about 2000 B.c. to the beginning of the Christian era, and to have remained relatively stable since then. The changes correlate favourably with transgressional periods recorded in Europe. The present rise of 8-9 in. a century may well be only a minor fluctuation in what is now an essentially stable ocean-level.

\section{Hatfield Technical College}

As from September next Hatfield Technical College will be renamed Hatfield College of Technology. Three departments of engineering have recently been formed, namely : the Department of Mechanical and Aeronautical Engineering (head of department, D. R. Samson); the Department of Industrial Engineering (head of department, J. D. Smith); the Department of Electrical Engineering (head of department, B. F. Gray). It is also announced that Dr. R. F. Robbins has succeeded Dr. Fred. Lester as head of the Department of Science.

\section{The Institute of Metals}

THe Council of the Institute of Metals has made the following awards of medals for 1961: Institute of Metals (Platinum) Medal, to Major C. J. P. Ball, chairman of Magnesium Elektron, Ltd., in recognition of his outstanding services to the non-ferrous metal industries and, in particular, to the magnesium industry; Rosenhain Medal, to Dr. P. B. Hirsch, of the Cavendish Laboratory, Cambridge, in recognition of his outstanding contributions in the fields of physical metallurgy and metal physics.

The following have been elected officers and members of the Council of the Institute of Metals : president, Prof. H. O'Neill (head of the Department of Metallurgy, University College of Swansea, University of Wales); past-president, Sir Ronald Prain (chairman and president, Rhodesian Selection Trust, Ltd.); vice-presidents, Mr. W. F. Randall (deputy chairman and managing director, Telcon Metals, Ltd.) and The Right Hon. The Earl of Verulam (chairman, Enfield Rolling Mills, Ltd.); ordinary members of Council, Mr. N. I. Bond-Williams (managing director, the Aston Chain and Hook Co., Ltd.); Prof. A. H. Cottrell (Goldsmiths' profossor of metallurgy, University of Cambridge); and Mr. G. A. Rider (deputy managing director, Birmid Industries, Ltd.).

\section{University News : Birmingham}

The Ford Foundation has given the University a grant of 440,000 dollars to support a programme of research extending over the next fifteen years in the Department of Anatomy into the reproductive physiology of monkeys. The Department has been made the recipient of this benefaction because, under the direction of Sir Solly Zuckerman, work of this nature has been one of its main interests for many years. 